\title{
Biodiversity of Parasitoids Present in Agroforestry in Brazil
}

\author{
Carlos Henrique Marchiori
}

\section{ABSTRACT}

The aim of this study is to report the parasitoids collected on many substrates in the agroforestry area in Brazil. The experimental study was carried out in an agroforestry area in the south of Goiás, Brazil. Traps made of metal containers. They served as baits to attract flies: fish, bovine kidneys, human feces and chicken viscera deposited inside metal containers, on a layer of sand. This sand was sieved after the pupae were extracted and subsequently placed individually in small glass containers to obtain flies and parasitoids. From 745 pupae of dipteran collected 684 parasitoids emerged from 111 pupae. The most frequent species in this study was Aphaereta sp. (Hymenoptera: Braconidae: Alysiinae) 52.6\%. The total percentage of parasitism obtained at work was 14.9\%. Brachymeria podagrica Fabricius (Hymenoptera: Chalcididae) was the species that presented the highest percentage of parasitism with $\mathbf{5 5 . 0 \%}$, parasitizing Ophyra aenescens L. (Diptera: Muscidae) on human feces substrate.

Keywords: Baits, Insect, Ophyra aenescens, Pachycrepoideus vindemmiae, Pests, Trap.

\section{INTRODUCTION}

Flies (Diptera) are accused of having strong potential as mechanical vectors of pathogens that cause carbuncle, mastitis, keratoconjunctivitis and other diseases, which can cause not only economic damage, but also lead animals to death. As these insects, management possibilities, besides the chemical control by means of insecticides may be used natural regulators of various pest species known both in agriculture and in animal breeding [1].

Among the natural regulators, we find parasitoids that are agents responsible for the reduction of flies that proliferate in bovine manure [2]. Parasitoids are essential for maintaining ecological balance and contribute to the diversity of other organisms.

Parasitoids, in addition to their importance in the biological control of insect pests, are important in Forensic Entomology (the study of insects and other arthropods associated with various criminal issues - serves as an auxiliary tool, for example, in the investigation of crimes against victims of violent death) [3].

The aim of this study is to report the parasitoids collected on many substrates in the agroforestry area in Brazil.

\section{MATERIAL AND METHODS}

The experimental study was carried out in an agroforestry area in the south of Goiás, Brazil. Traps made of metal containers (Fig. 1). They are traps that are built with a metal container, painted externally with black matte paint, measuring about $20 \mathrm{~cm}$ in height and $9 \mathrm{~cm}$ in diameter, with two venetian openings, made in the lower third to allow the entry of insects [4].

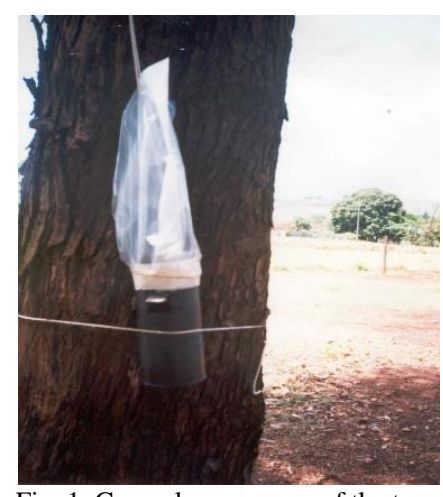

Fig. 1. General appearance of the trap.

They served as baits to attract flies: fish, bovine kidneys, human feces, and chicken viscera deposited inside metal containers, on a layer of sand. Fortnightly, four traps were used, hanging from trees one meter from the ground, two meters from each other. To obtain parasitoids, the content of the traps was placed in plastic containers containing a layer of sand to serve as a substrate for the larvae pupation. This sand was sieved after the pupae were extracted and subsequently placed individually in small glass containers to obtain flies and / or parasitoids [5]. The experiment was carried out from January to December 2006.

From 745 pupae of dipteran collected 684 parasitoids emerged from 111 pupae (Table I).

The percentage of species collected in this study was: Pachycrepoideus vindemmiae (Rondani) (Hymenoptera: Pteromalidae) (25/684) with 3.7\%, Brachymeria podagrica Fabricius (Hymenoptera: Chalcididae) (68/684) with $10.0 \%$, 
Nasonia vitripennis (Walker) (Hymenoptera: Pteromalidae) (231/684) with $33.8 \%$ and Aphaereta sp. (Hymenoptera: Braconidae: Alysiinae) (360/684) 52.6\%. The most frequent species in this study was Aphaereta sp. Probably due to his polyphagous, gregarious and generalist habit.

Alysiinae are cenobiont endoparasitoids of brachycous dipterans; the Alysiini occur associated with more than 20 Diptera families. Many of their hosts occur associated with decomposing manure, fungi or plant and animal matter; few parasitize Tephritidae larvae. The pupation of the parasitoid occurs inside the pupae of the host. Most are solitary parasitoids; some species of Aphaereta are gregarious. In Brazil, studies on Alysiinae parasitoids of muscoid dipterans refer mainly to species of the Aphaereta genera [6].

The number of parasitized pupae obtained the total percentage of parasitism / total number of pupae collected $\mathrm{x}$ 100. According to the formula, the total percentage of parasitism obtained at work was (111/745) $14.9 \%$. The total percentage of parasitism obtained by the species in this study was $P$. vindemmiae $(25 / 745)$ with $3.4 \%, B$. podagrica $(68 / 745)$ with $9.1 \%, N$. vitripennis $(10 / 745)$ with $0.9 \%$ and Aphaereta sp. (8/745) 1.1\%. Brachymeria podagrica presented the highest total percentage of parasitism obtained by the species in this study. Probably due to the competitive ability of the young forms.

The percentage of species collected in this study was: $P$. vindemmiae $(25 / 684)$ with $3.7 \%$, B. podagrica (68/684) with $10.0 \%, N$. vitripennis (231/684) with $33.8 \%$ and Aphaereta sp. (360/684) 52.6\%. The most frequent species in this study was Aphaereta sp. Probably due to his polyphagous, gregarious and generalist habit.

Alysiinae are cenobiont endoparasitoids of brachycous dipterans; the Alysiini occur associated with more than 20 Diptera families. Many of their hosts occur associated with decomposing manure, fungi or plant and animal matter; few parasitize Tephritidae larvae. The pupation of the parasitoid occurs inside the pupae of the host. Most are solitary parasitoids; some species of Aphaereta are gregarious. In Brazil, studies on Alysiinae parasitoids of muscoid dipterans refer mainly to species of the Aphaereta genera [6].

The number of parasitized pupae obtained the total percentage of parasitism / total number of pupae collected $\mathrm{x}$ 100. According to the formula, the total percentage of parasitism obtained at work was (111/745) $14.9 \%$. The total percentage of parasitism obtained by the species in this study was $P$. vindemmiae $(25 / 745)$ with $3.4 \%, B$. podagrica $(68 / 745)$ with $9.1 \%, N$. vitripennis $(10 / 745)$ with $0.9 \%$ and
Aphaereta sp. (8/745) 1.1\%. Brachymeria podagrica presented the highest total percentage of parasitism obtained by the species in this study. Probably due to the competitive ability of the young forms.

The Chalcididae are cosmopolitan insects with a high diversity in the tropics including approximately 1.500 species. They are predominantly solitary endoparasitoids. Species of the genus Brachymeria are important primary parasitoid of muscoid Diptera, such as species of the Sarcophagidae and Calliphoridae families. Some species are of economic importance, for they attack insect pests. The species $B$. podagrica occurs almost everywhere in the world and lives associated with synanthropic and other Diptera flies emerging from their pupae [7].

Percentage of parasitism for each species of parasitoid was calculated according to the formula: number of parasitized puparium/by the number of host puparium $\mathrm{x}$ hundred. According to this formula B. podagrica was the species that presented the highest percentage of parasitism (11/20) with $55.0 \%$, parasitizing Ophyra aenescens (Diptera: Muscidae) on human feces substrate. This fact may be influenced by variations in the quality and availability of resources, in the ability to search for parasitoids and by the density of the hosts (Table I).

Pachycrepoideus vindemmiae generalist wasp that attacks pupae of several species cyclorrhaphous dipteran as a primary parasitoid. $P$. vindemmiae pupae remain concealed under the soil or manure until they are ready to emerge as adults.

Due to the controlling action of the parasitoids, there would be an explosion in the populations of herbivores, which would lead to the destruction of the plant species they consume. This makes them essential for maintaining ecological balance and a force that contributes to the diversity of other organisms [9].

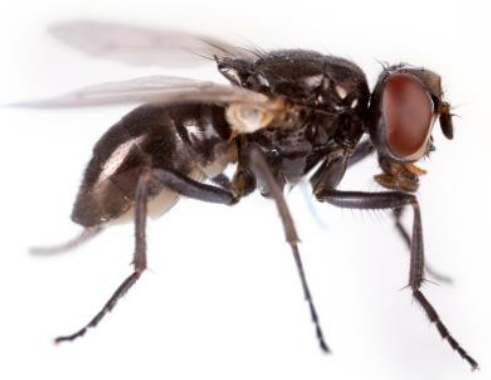

Fig. 2. Ophyra aenescens (Diptera: Muscidae) Source: https://www.flickr.com/photos/hans_smid/10931538014.

TABLE I. PARASITOIDS AND THEIR DiPTERANS Hosts COLlECTED IN THE STATE of GoiÁs, MidwEST REGION OF BRAZIL

\begin{tabular}{|c|c|c|c|c|c|c|}
\hline Species of Diptera & $\begin{array}{c}\text { Number of } \\
\text { pupae }\end{array}$ & Baits & Species of Hymenoptera & $\begin{array}{c}\text { Number de } \\
\text { specimens }\end{array}$ & $\begin{array}{c}\text { Pupae } \\
\text { parasitized } \\
\end{array}$ & $\%$ \\
\hline Chrysomya albiceps & 120 & Bovine kidneys & Pachycrepoideus vindemiae & 2 & 2 & 1.6 \\
\hline Fannia pusio & 40 & & Nasonia vitripennis & 143 & 4 & 10.0 \\
\hline Chrysomya megacephala & 40 & Chicken & Brachymeria podagrica & 6 & 6 & 15.0 \\
\hline Oxysarcodexia thornax & 33 & & $\begin{array}{c}\text { Brachymeria podagrica } \\
\text { Nasonia vitripennis }\end{array}$ & $\begin{array}{l}10 \\
25\end{array}$ & $\begin{array}{c}10 \\
2\end{array}$ & $\begin{array}{c}30.3 \\
6.1\end{array}$ \\
\hline Peckia chrysostoma & 104 & & $\begin{array}{l}\text { Brachymeria podagrica } \\
\quad \text { Nasonia vitripennis }\end{array}$ & $\begin{array}{l}34 \\
23\end{array}$ & $\begin{array}{c}34 \\
1\end{array}$ & $\begin{array}{c}32.7 \\
1.0\end{array}$ \\
\hline Musca domestica & 236 & Human feces & Pachycrepoideus vindemiae & 18 & 18 & 7.6 \\
\hline Ophyra aenescens & 20 & & Brachymeria podagrica & 11 & 11 & 55.0 \\
\hline Sarcophagula sp. & 47 & & Pachycrepoideus vindemiae & 5 & 5 & 10.6 \\
\hline Chrysomya albiceps & 43 & Fish viscera & Nasonia vitripennis & 40 & 3 & 7.0 \\
\hline Peckia chrysostoma & 42 & & $\begin{array}{c}\text { Aphaereta sp. } \\
\text { Brachymeria podagrica }\end{array}$ & $\begin{array}{c}360 \\
7\end{array}$ & $\begin{array}{l}8 \\
7\end{array}$ & $\begin{array}{l}19.4 \\
16.6\end{array}$ \\
\hline Total & 745 & -- & & 684 & 111 & -- \\
\hline
\end{tabular}




\section{CONCLUSION}

The most frequent species in this study was Aphaereta sp. $52.6 \%$. The total percentage of parasitism obtained at work was $14.9 \%$. B. podagrica was the species that presented the highest percentage of parasitism with $55.0 \%$, parasitizing. Ophyra sp. (Diptera: Muscidae) on human feces substrate.

\section{REFERENCES}

[1] G. A. R. Silveira, N. G. Madeira and A. M. L. Azeredo-Espin, "Levantamento de microhimenoptera parasitóides de dípteros de importância médico-veterinária no Brasil," Memórias do Instituto Oswaldo Cruz, v. 84, pp. 505-510, 1989.

[2] F. T. P. S Sereno and D. Neves, "Microhimenópteros (Pteromalidae) parasitóides de Diptera (Muscidae, Otitidae) em uma granja de bovinos em Igarapé, Estado de Minas Gerais, Brasil,” Revista Brasileira de Entomologia, v. 37, pp. 563-567, 1993.

[3] J. R. Pujol-Luz, L. Arantes, L. Chaves and R. Constantino, "Cem anos da Entomologia Forense no Brasil (1908-2008)". Revista Brasileira de Entomologia, vol. 52, pp. 485-492, 2008.

[4] M. J. M. Ferreira, "Sinantropia de dípteros muscoideos de Curitiba, Paraná, Calliphoridae," Revista Brasileira de Biologia, vol. 38, pp. 445454, 1978.
[5] C. H. Marchiori,'Traps for specimen collection of insect in Brazil,"O Biológico, v.78, n.1, pp.1-5, 2016.

[6] R. F. Harwood and M. T. James, Entomology in human and animal health, 7 st. ed. New York, USA: Macmillan, 1979.

[7] P. E. Hanson and I. D. Gauld, The Hymenoptera of Costa Rica, 1st ed. Oxford, U.K.: University Press Oxford, 1995

[8] J. M. D'Almeida, C. Borges and C. A. Gonçalves, "Desenvolvimento pós-embrionário de Ophyra aenescens (Wiedemann, 1830) (Diptera: Muscidae) em Diferentes Dietas, sob Condições de Laboratório," Memórias do Instituto Oswaldo Cruz, vol. 94, no. 1, pp. 123-126, 1999.

[9] D. Scatoli and A. M. P Dias, "A fauna de Braconidae (Hymenoptera) como bioindicadora do grau de preservação de duas localidades do Estado do Paraná," Revista Brasileira de Ecologia, vol. 1, pp. 84-87, 1997.

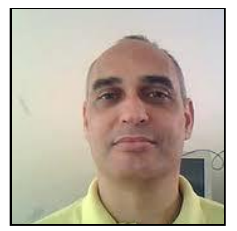

Dr. Carlos Henrique Marchiori is graduated in Biological Sciences from the Federal University of Uberlândia (1989), master's degree in Parasitology from the State University of Campinas (1993) and a $\mathrm{PhD}$ in Parasitology from the State University of Campinas (1997). He has experience in parasitology, with an emphasis in entomology and taxonomy of parasitoids, acting on the following topics: Diptera, Hymenoptera, parasitoids, biological control, and natural enemy. 